\section{Discussion}

Infections with Str. pyogenes are important not only because of the direct pyogenic action but also because of the potentially dangerous sequelae. Rheumatic fever or acute glomerulonephritis may follow upper respiratory tract infection though only nephritis has been described after streptococcal skin infections. The occurrance of nephritis is not related to the severity of the skin lesion, and while it may be associated with widespread impetigo it may also follow minor skin infections. Though only certain types of group A streptococci are nephritogenic all infections with this streptococcal group should be treated seriously.

The potential danger of contaminated dust had been recognized by White (1936), who described pharyngitis developing in a maid who had cleaned a room in which a woman with streptococcal puerperal fever had been nursed. Measures taken to control this environmental reservoir have included the oiling of both the floor and blankets. (Thomas and van den Ende, 1941; White et al., 1944).

In the outbreak we saw, control measures were aimed at the removal of dust and the disinfection of surfaces. The routine cleaning procedures were modified to ensure that the level of dust was kept to a minimum. It was not possible to remove dust adequately from the wood strip floor in the gymnasium until the floor had been sanded and sealed. In residential communities it is advisable that all floors should be sealed and able to withstand regular washing.

Studies in the Red Lake Indian Reservation (Ferrieri et al., 1972; Dajani et al., 1972) suggest that streptococcal infections of both the upper respiratory tract and the skin were preceded by skin colonization. Serial observations on individual children showed that group A streptococci could be recovered from normal skin before the development of skin infections. The mean interval between acquisition and infection was 10 days. A further interval of 14-20 days followed before streptococci could be isolated from the nose or throat. Once skin infection was established there was rapid spread within a family.

During our outbreak the carriage of streptococci on normal skin and in the upper respiratory tract was not assessed. No boy, however, developed a proven streptococcal skin infection during the first 12 days after admission to the centre though all the boys took part in exercises and games during this time. The lack of overt infection during the first 12 days may represent a period of skin carriage.

The principle of containment is important in the control of any communicable disease. It is now the policy in the centre where this outbreak occurred to cover all septic lesions with a waterproof dressing and isolate the boy if necessary. Prompt bacteriological examination is undertaken of all septic lesions. It is hoped that these measures will prevent any further similar outbreaks.

The role of dust as a reservoir of infection in this outbreak illustrates the importance of studying not only the patient but also his environment.

We thank the staff of the Cross-Infection Reference Laboratory, Colindale, for typing the streptococci and measuring the antibody levels; the staff of the Public Health Laboratory, Epsom, for typing the staphylococci; the staff of the detention centre for their cooperation; and all our colleagues for their helpful advice.

\section{References}

Anthony, B. F., et al. (1967). Lancet, 2, 787.

Dajani, A. S., Ferrieri, P., and Wannamaker, L. W. (1972). Fournal of Clinical Investigation, 51, 2863.

Dillon, H. C. (1968). American fournal of Diseases of Children, 115, 530.

Dillon, H. C. (1972). In Streptococci and Streptococcal Diseases, ed. L. W. Wannamaker and J. M. Matsen, p. 571 . Academic Press.

Wannamaker and J. M. Matsen, p. 571 . Academic Press.
Ferrieri, P., et al. (1972). Fournal of Clinical Investigation, 51, 2851.

Ferrieri, P., et al. (1972). Fournal of Clinical Investigation, 51, 2851. Broadsheet No. 25. London, Association of Clinical Pathologists.

Kaplan, E. L., et al. (1970). Fournal of Clinical Investigation, 49, 1405.

Kleinman, H. (1954). Minnesota Medicine, 37, 479.

Nelson, J., Ayoub, E. M., and Wannamaker, L. W. (1968). Fournal of Laboratory and Clinical Medicine, 71, 867.

Rammelkamp, C. H.; et al. (1958). Fournal of Hygiene, Cambridge, 56, 280. Rosenbach, F. J. (1884). Mikroorganismen bei den Wundinfektionskrankheiten. Wiesbaden, Bergmann.

Simon, N. S., Potter, E. V., Seigel, A. C., McAninch, J., Poon-King, T., Humair, L. and Earle, D. P. (1965). Epidemic nephritis in Trinidad, fournal of Laboratory and Clinical Medicine, 66, 1022

Thomas, J. C., and van den Ende, M. (1941). British Medical fournal, 1, 953

Wannamaker, L. W. (1970). New England fournal of Medicine, 282, 23.

Wannamaker, L. W. (1970). Ner

Widdowson, J. P., Maxted, W. R., and Pinney, A. M. (1971). Fournal of Hygiene, Cambridge, 69, 553.

Wright, J., Cruickshank, R., and Gunn, W. (1944). British Medical fournal, 1,611 .

\title{
Relapses after Withdrawal of Proguanil Treatment in Tropical Splenomegaly Syndrome
}

\author{
ABA. S. DAVID-WEST
}

British Medical fournal, 1974, 3, 499-501

\section{Summary}

After the remission of symptoms and reduction in spleen size while on proguanil therapy four patients with the tropical splenomegaly syndrome defaulted from treatment. The withdrawal of proguanil caused a recrudescence of original symptoms, splenomegaly, and a return of the initially raised serum IgM. Complete return to normal values was again effected with proguanil therapy. \footnotetext{
Department of Haematology, University College Hospital, Ibadan,
Nigeria

ABA S. DAVID-WEST, M.B., PH.D., Senior Registrar
}

The role of the spleen in the tropical splenomegaly syndrome in the production of the raised serum IgM is discussed. These patients should be educated as to the nature of their disease and the importance of continued medical treatment.

\section{Introduction}

The tropical splenomegaly syndrome is associated with anaemia, lymphocytosis in the peripheral blood and bone marrow, hepatic sinusoidal lymphocytosis, and a raised serum IgM. (British Medical fournal, 1967; Pryor, 1967; Richmond et al., 1967; Ziegler et al., 1969; Sagoe, 1970). Tests of immunological competence-phytohaemagglutinin-induced lymphocyte transformation and delayed hypersensitivity skin tests-give normal results. Proguanil and other antimalarials 
have been successfully used in the treatment of the syndrome in Ibadan (Watson-Williams and Allan, 1968; Sagoe, 1970), Uganda (Stuiver et al., 1971), Zambia (Lowenthal et al., 1971), and New Guinea (Crane et al., 1973). The use of proguanil not only diminishes the spleen size but also normalizes the haematological and serological values found in the syndrome.

This report illustrates the effect of withdrawal of proguanil on the course of the syndrome after complete remission of symptoms and signs.

\section{Patients and Methods}

Four adult patients with a diagnosis of the tropical splenomegaly syndrome were followed up at the haematology clinic of the University College Hospital while they were on proguanil $100 \mathrm{mg} /$ day (after an initial dose of chloroquine $800 \mathrm{mg}$ ).

Spleen sizes were measured from the costal margin at the anterior axillary line to the apex of the spleen. Hepatic sinusoidal lymphocytosis in liver biopsy specimens was graded according to Marsden et al. (1965).

Immunoglobulins IgG, IgA, and IgM were determined on commercially prepared immunoplates according to the method of Fahey and McKelvey (1965). Phytohaemagglutinininduced lymphocyte transformation tests (PHA-L.T.T.) were performed as previously described (Sagoe, 1970). Standard haematological techniques were employed.

\section{Clinical and Laboratory Findings}

The spleen and liver measurements, haematological and serum immunoglobulin values, and the results of the PHAL.T.T. are shown in the table on presentation, during treatment, and during subsequent relapse in four patients.

\section{CASE 1}

The patient was a 60 -year-old woman who presented with a sixmonth history of pain and aching on the left side of her abdomen. In the preceeding two months she had increasing weakness which prevented her from carrying out her daily household duties. On examination her conjunctivae were pale. The spleen measured $16 \mathrm{~cm}$ and the liver $3 \mathrm{~cm}$. The haematocrit reading was $33 \%$, W.B.C. was $4,100 / \mathrm{mm}^{3}$ ( $70 \%$ lymphocytes), and platelets were $83,000 / \mathrm{mm}^{3}$. The haemoglobin type was A. No malaria parasites were seen in the peripheral blood. The marrow showed a normoblastic hyperplasia and was moderately infiltrated by small lymphocytes. PHA-L.T.T. result was normal and hepatic sinusoidal lymphocytosis was grade 0 . Total serum protein was $8.7 \mathrm{~g} / 100$ $\mathrm{ml}$, albumin was $2.9 \mathrm{gm} / 100 \mathrm{ml}$, and globulins were $5.8 \mathrm{~g} / 100$ $\mathrm{ml}$. Immunoglobulin values are shown in the table.
The patient responded to daily proguanil treatment and in two months the spleen measured $9 \mathrm{~cm}$ and the liver became impalpable. The anaemia was corrected, the peripheral blood lymphocytosis diminished, and the initial thrombocytopenia reverted to a normal value of $264,000 / \mathrm{mm}^{3}$. Likewise the serum IgM fell to 560 $\mathrm{mg} / 100 \mathrm{ml}$.

She defaulted for two months and then returned with symptoms of weakness and tiredness. The spleen and liver had returned to their original sizes, there was anaemia, and the serum IgM was again raised. This time it took nine months for the spleen to halve its initial value and for the anaemia to be corrected. Twelve months after the second presentation and continued proguanil treatment the spleen reduced to $5 \mathrm{~cm}$ and the liver became impalpable. She had gained $3 \mathrm{~kg}$ in weight, and she has since continued to enjoy good health.

\section{CASE 2}

The patient was a 35-year-old trader and she presented with a five-year history of a lump in the left side of her abdomen. This had given her little discomfort until four months before presentation when the mass caused her pain occasionally. Furthermore, she became increasingly tired and was unable to continue her work as before. On examination she was pale and the abdomen was distended by a large firm spleen measuring $28 \mathrm{~cm}$; the liver was $10 \mathrm{~cm}$. The haematocrit reading was $24 \%$, W.B.C. $2,900 / \mathrm{mm}^{3}$ ( $58 \%$ lymphocytes), and platelets numbered $146,000 / \mathrm{mm}^{3}$. Haemoglobin type was A. Thick films for malaria parasites were negative. The marrow showed a normoblastic hyperplasia with some infiltration by small and large lymphocytes. Hepatic sinusoidal lymphocytosis was grade 0 . Total serum protein was $8.5 \mathrm{~g} / 100 \mathrm{ml}$, albumin was $3.2 \mathrm{~g} / 100 \mathrm{ml}$, and globulins were $5.3 \mathrm{~g} / 100 \mathrm{ml}$. She took proguanil for 16 months, during which time the spleen reduced in size to $8 \mathrm{~cm}$, the liver became impalpable, and the haematocrit reading rose to $40 \%$.

No sooner was she feeling well than she defaulted for 18 months. Meanwhile the spleen increased to $22 \mathrm{~cm}$, and the liver was $4 \mathrm{~cm}$. The initial anaemia returned together with thrombocytopenia, and serum IgM was raised (see table and fig.). She was treated with proguanil once again, and in the next 21 months both the liver and spleen became impalpable, the haematocrit reading rose to $36 \%$, the raised serum IgM fell to within normal values, and she gained $1 \mathrm{~kg}$ in weight.

\section{CASE 3}

This 33-year-old housewife presented with a three-month history of fullness in the left side of her abdomen and occasional fever and weakness. On examination she had conjunctival pallor. The spleen measured $20 \mathrm{~cm}$ and the liver $9 \mathrm{~cm}$. Haemotological and serological data are shown in the table. The haemoglobin type was A. No malaria parasites were found in thick blood films. PHA-L.T.T. result was normal and hepatic sinusoidal lymphocytosis was grade 1. Proguanil therapy was begun, and after 41 months her spleen and liver became impalpable and the haematological and serological indices became normal.

\begin{tabular}{|c|c|c|c|c|c|c|c|c|c|c|c|c|}
\hline & & \multirow{2}{*}{$\begin{array}{l}\text { Spleen } \\
(\mathrm{cm})\end{array}$} & \multirow{2}{*}{$\begin{array}{l}\text { Liver } \\
(\mathrm{cm})\end{array}$} & \multicolumn{5}{|c|}{ Haematological Values } & \multicolumn{3}{|c|}{$\begin{array}{c}\text { Serum Immunoglobulins* } \\
(\mathrm{mg} / 100 \mathrm{ml})\end{array}$} & \multirow{2}{*}{$\begin{array}{l}\text { PHA- } \\
\text { L.T.T. } \\
\left(\begin{array}{c}\% \\
\%\end{array}\right)\end{array}$} \\
\hline & & & & $\underset{(\mathrm{mg} / 100 \mathrm{ml})}{\mathrm{Hb}}$ & $\underset{(\%)}{\text { P.C.V. }}$ & $\underset{\mathrm{mm}^{3}}{\text { W.B.C.l }}$ & $\begin{array}{l}\text { \% Lymph- } \\
\text { ocytes }\end{array}$ & Platelets & $\operatorname{IgM}$ & IgG & $\operatorname{IgA}$ & \\
\hline $\begin{array}{l}\text { Case } 1 \\
\text { Case } 2 \\
\text { Case } 3 \\
\text { Case } 4\end{array}$ & $\begin{array}{l}\text { At Presentation } \\
\text { 1st Remission } \\
\text { 2nd Presentation } \\
\text { 2nd Remission } \\
\text { At Presentation } \\
\text { 1st Remission } \\
\text { 2nd Presentation } \\
\text { 2nd Remission } \\
\text { At Presentation } \\
\text { 1st Remission } \\
\text { 2nd Presentation } \\
\text { 2nd Remission } \\
\text { At Presentation } \\
\text { 1st Remission } \\
\text { 2nd Presentation } \\
\text { 2nd Remission }\end{array}$ & $\begin{array}{r}16 \\
9 \\
16 \\
5 \\
28 \\
8 \\
22 \\
0 \\
20 \\
0 \\
12 \\
0 \\
14 \\
0 \\
17 \\
0\end{array}$ & $\begin{array}{r}3 \\
0 \\
3 \\
0 \\
10 \\
0 \\
4 \\
0 \\
9 \\
0 \\
2 \\
0 \\
0 \\
0 \\
2 \\
0\end{array}$ & $\begin{array}{r}11.4 \\
10.4 \\
13.2 \\
7.1 \\
13.6 \\
7.9 \\
12.9 \\
7.9\end{array}$ & $\begin{array}{l}33 \\
37 \\
31 \\
39 \\
24 \\
40 \\
24 \\
36 \\
25 \\
37 \\
30 \\
43 \\
16 \\
37 \\
17 \\
42\end{array}$ & $\begin{array}{r}4,100 \\
9,600 \\
5,350 \\
8,900 \\
2,900 \\
6,850 \\
5,100 \\
4,600 \\
22,600 \\
6,100 \\
17,100 \\
4,450 \\
3,600 \\
7,800 \\
7,900 \\
5,600\end{array}$ & $\begin{array}{l}70 \\
35 \\
62 \\
42 \\
58 \\
23 \\
57 \\
40 \\
82 \\
52 \\
65 \\
51 \\
53 \\
48 \\
48 \\
32\end{array}$ & $\begin{array}{r}83,000 \\
264,000 \\
108,000 \\
182,000 \\
146,000 \\
150,000 \\
83,000 \\
92,000 \\
198,000 \\
182,000 \\
152,000 \\
220,000 \\
82,000 \\
105,000 \\
83,000 \\
133,000\end{array}$ & $\begin{array}{l}2,600 \\
560 \\
2,600 \\
230 \\
\text { N.D. } \\
\text { N.D. } \\
2,200 \\
132 \\
1,350 \\
120 \\
5,200 \\
210 \\
\text { N.D. } \\
\text { N.D. } \\
1,800 \\
400\end{array}$ & $\begin{array}{l}2,500 \\
3,250 \\
3,000 \\
4,000 \\
\text { N.D. } \\
\text { N.D. } \\
1,800 \\
1,850 \\
1,600 \\
2,300 \\
2,010 \\
2,200 \\
\text { N.D. } \\
\text { N.D. } \\
1,800 \\
1,320\end{array}$ & $\begin{array}{r}\text { N.D. } \\
\text { N.D. } \\
210 \\
190 \\
\text { N.D. } \\
\text { N.D. } \\
195 \\
260 \\
130 \\
130 \\
200 \\
190 \\
\text { N.D. } \\
\text { N.D. } \\
\text { 260 } \\
\text { N.D. }\end{array}$ & $\begin{array}{c}75 \\
\text { N.D. } \\
69 \\
78 \\
\text { N.D. } \\
\text { N.D. } \\
90 \\
82 \\
72 \\
\text { N.D. } \\
83 \\
74 \\
\text { N.D. } \\
\text { N.D. } \\
73 \\
81\end{array}$ \\
\hline
\end{tabular}

*Normal values for adult Nigerians: IgG $=1,250-4,100 \mathrm{mg} / 100 \mathrm{ml}$ (mean $2,500 \mathrm{mg} / 100 \mathrm{ml}) . \mathrm{IgA}=60-360 \mathrm{mg} / 100 \mathrm{ml}(\mathrm{mean} 183 \mathrm{mg} / 100 \mathrm{ml}) . \mathrm{IgM}=50-400 \mathrm{mg} / 100 \mathrm{ml}$ (mean $189 \mathrm{mg} / 100 \mathrm{ml}$ ). 


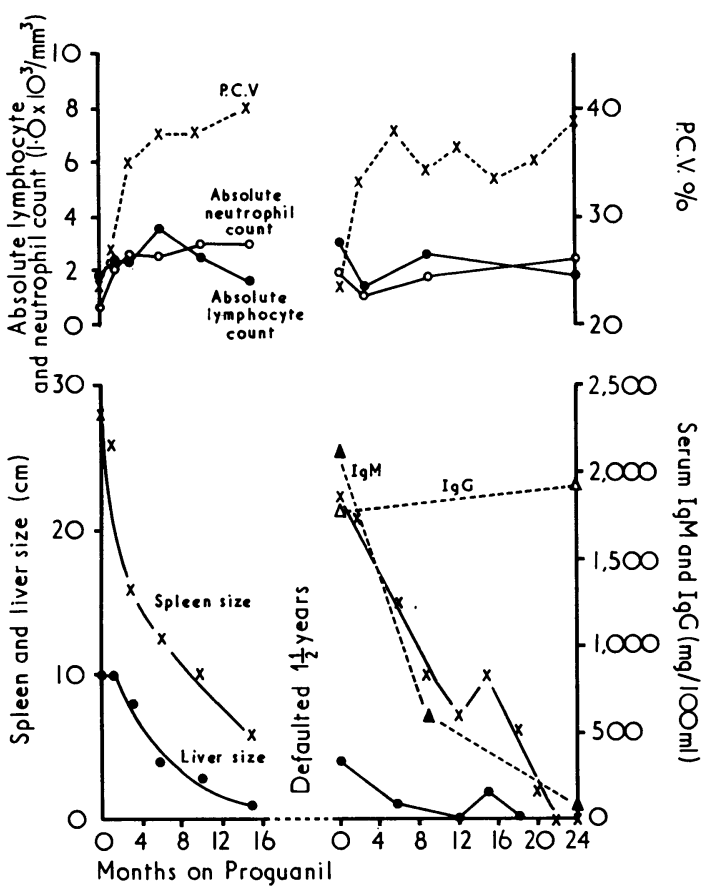

Clinical course of a patient with tropical splenomegaly syndrome who defaulted for 18 months (case 4).

Having felt very well she defaulted from treatment for 11 months and presented again with a recrudescence of her previous symptoms of abdominal swelling, fever, and casy fatigue. The spleen had increased to $12 \mathrm{~cm}$ and the liver was $2 \mathrm{~cm}$. There was anaemia and leucocytosis with an absolute lymphocytosis, as was present initially. The serum IgM was raised to $5,200 \mathrm{mg} / 100 \mathrm{ml}$. Proguanil therapy for 10 months once again reduced her organomegaly and normalized haemotological and serological values.

\section{CASE 4}

This 44-year-old female shopkeeper presented with a six-year history of left-sided abdominal pain, anorexia, increasing weakness, and some weight loss. On examination she had conjunctival pallor and a distended abdomen which was minimally tender over the splenic area. The spleen was $14 \mathrm{~cm}$ and there was no hepatomegaly. Some of the laboratory data are shown in the table. The haemoglobin type was A. Thick films for malaria parasites were negative. The marrow showed early transitional megaloblastic changes with moderate erythroid hyperplasia. Hepatic sinusoidal lymphocytosis was grade 0 .

After taking daily proguanil for 24 months the spleen became impalpable and her anaemia was corrected. She continued taking proguanil for another year and then defaulted for 18 months. On her return there was recrudescence of her original symptoms, anaemia, splenomegaly of $17 \mathrm{~cm}$, and the liver was enlarged $2 \mathrm{~cm}$. Serum IgM was raised. She again responded sucoessfully to proguanil therapy and in eight months the spleen and liver became impalpable. She continued to enjoy good health since then.

\section{Discussion}

\section{PROGUANIL THERAPY}

These cases illustrate the importance of a diligent follow up of patients with the tropical splenomegaly syndrome, which can only be successful if the patient also realizes what is at stake. It is important to impress on patients that the daily intake of proguanil is essential to alleviate their symptoms and reduce the spleen size. Should they stop treatment there will be a relapse of their symptoms and further enlargement of the spleen. In case 4 the spleen became larger than it had been when the patient originally presented. In rural areas where the follow up of patients may be difficult owing to distance, shortage of medical personnel, or default by patients the long-acting antimalarial cycloguanil palmoate $(350 \mathrm{mg}$ intramuscularly every four months) should be an advantage.

Proguanil has been used continuously as prophylaxis for malaria for over 20 years in some patients in West Africa without any detectable toxic manifestations. Daily therapy with proguanil rather than a weekly dose of pyrimethamine is more easily remembered and is also psychologically more effective.

Drug resistance to proguanil and its metabolite cycloguanil is known in other parts of the world. Combination chemotherapy with another antimalarial drug with a different mode of action on the parasite may be useful to combat this difficulty. Peters (1970) has reported a potentiation effect on proguanil by menoctone, a naphthoquinone derivative, against Plasmodium berghei infection in mice. Its usefulness in man still needs to be evaluated.

\section{SPLEEN AND RAISED IgM}

Raised serum IgM values have been used as a diagnostic pointer to the tropical splenomegaly syndrome (Sagoe, 1970). In two patients (cases 1 and 3) where IgM values were measured at presentation they were grossly raised. In all four patients the serum IgM values were again raised during the relapse when the spleen sizes increased, and the values fell to normal again as the spleen reduced in size. It is not certain how often the spleen can enlarge and reduce in size or whether a stage may be reached when the splenomegaly would be refactory to proguanil treatment.

Histologically the spleen in the syndrome shows infiltration by numerous lymphocytes, plasma cells, and histiocytes, with lymphoid cell rosettes around macrophages in the dilated sinusoids (Sagoe and Edington, 1972). These appearances possibly represent abnormal exaggerated host responses to extraneous antigens, malaria in particular, and these would be part of the underlying mechanism for the splenic tissue hyperplasia and the accompanying increase in serum IgM in the tropical splenomegaly syndrome.

\section{PROGNOSIS}

With adequate medical care patients with the syndrome should expect to lead a normal life. The return of haematological values to normal and alleviation of symptoms is usually prompt once the sizes of the spleen is reduced with treatment. The patient must, however, be educated about the nature of his disease and the need for continuous proguanil therapy which may be life-long. Regular medical supervision should be made available in addition to a good doctor-patient relationship.

\section{References}

British Medical fournal, (1967). 4, 614.

Crane, G. G., Hudson, P., and Hudson, B. E. T. (1973). Paoua and New Guinea Medical fournal, 16, 46.

Fahey, S. L., and Mckelvey, E. N. (1965). Fournal of Immunology, 94, 84

Lowenthal, M. N., O'Riordan, E. C., and Hutt, M. S. R. (1971). British Medical fournal, 1, 429.

Marsden, P. D., et al. (1965). British Medical fournal, 1, 89.

Peters, W. (1970). Transactions of the Royal Society of Tropical Medicine and Hygiene, 64, 462.

Pryor, D. S. (1967). Quarterly Fournal of Medicine, 36, 321.

Richmond, J., et al. (1967). British fournal of Haematology, 13, 348.

Sagoe, A. S. (1970). British Medical fournal, 3, 378.

Sagoe, A. S., and Edington, G. M. (1972). West African Medical Fournal, 21, 168 .

Stuiver, P. C., et al. (1971). British Medical fournal, 1, 426

Watson-Williams, E. J., and Allan, N. C. (1968). British Medical fournal,

Ziegler, J. C., Cohen, M. H., and Hutt, M. S. R. (1969). British Medical fournal, 4, 15. 